\title{
Environmental protection as a global bioethical principle: Protestant faith tradition in conversation with United Nations Educational, Scientific and Cultural Organization
}

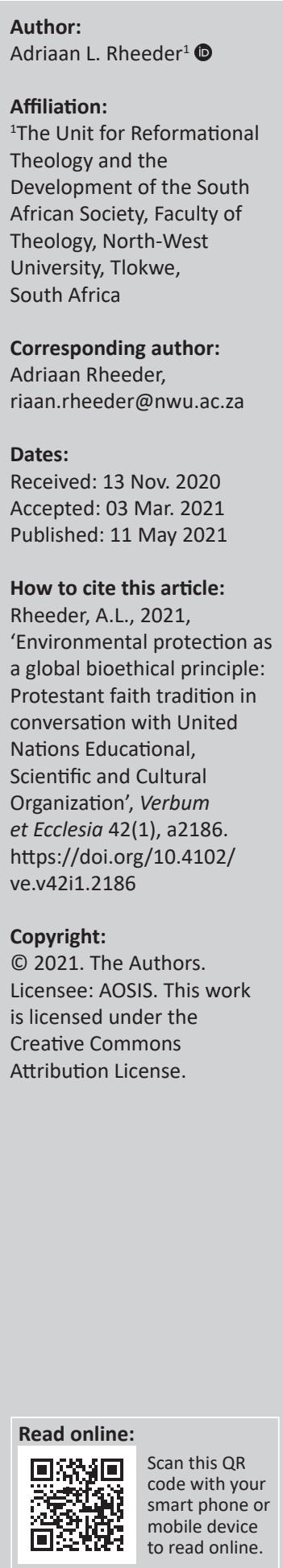

The Universal Declaration on Bioethics and Human Rights (UDBHR) is an important, modern human rights instrument regulating global bioethical challenges. The Protestant faith tradition was excluded from any discourse regarding the UDBHR; consequently, the universality and credibility, especially in Protestant circles, have been questioned. For the Protestant faith tradition, the voice of the Bible is decisive. An ethical foundation for article 17 of the UDBHR (enviromental protection and health) is, therefore, important, as it can contribute to the internalisation of the principle. In the analysis of article 17, it has been shown that the international community is convinced that an irrefutable relationship exists between nature and the health of the human interconnectedness. A damaged creation harms the health of the human and, therefore, the protection of nature is an indisputable obligation. From a Protestant ethical perspective, this global principle could be associated with or founded on the themes of creation, sin, covenant, Christology and eschatology. Grounded in this preliminary evaluation, article 17 can be supported by the global Protestant community. A few facts from South Africa indicate the necessity of promoting the global bioethical principle in this country.

Intradisciplinary and/or interdisciplinary implications: This study is an interdisciplinary analysis in the sense that it focuses on Theology and Human Rights Law within the context of Global Bioethics. It challenges the view that the Protestant perspective can be excluded in the discourse regarding the relation between environment and human health (article 17 of the United Nations Educational, Scientific and Cultural Organization [UNESCO] Bioethics Declaration).

Keywords: environment; biosphere; biodiversity; global bioethics; UNESCO; protestant faith tradision; creation; sin; covenant; christology; eschatology.

\section{Introduction}

The discipline of bioethics as differentiated from medical ethics originated in the 70s of the previous century. It differs from medical ethics in respect of the fact that it focuses not only on the needs and issues of the individual but also on social and environmental aspects connected with health. It has become clear that biomedical ethical proposals and solutions alone are not sufficient for promoting health and that the input of social, economic and environmental determinants of health is necessary (Ten Have 2019:17). Van Renselaer Potter (1911-2001), an American oncologist, also the first person to use the term bioethics, used cancer as an example to explain bioethics. In the ethical narrative of cancer, the emphasis cannot be on the medical and biological aspects of the individual person, for example the right to health, genetic predisposition and treatment, but part of the ethical context also comprises the social discourse, for example cigarette smoking and air pollution (Ten Have 2019:2-4).

A special milestone in the development of global bioethics is the acceptance of the Universal Declaration on Bioethics and Human Rights (hereafter UDBHR) of the United Nations Educational, Scientific and Cultural Organization (hereafter UNESCO) by the member states in 2005. The objective of the UDBHR is to unite the global community in terms of bioethical ideals (soft law), which combine individual values (articles 3-7) with social (articles 8-16) and environmental aspects (article 17) of health. Connecting the environment and health is not a very new idea, but the focus on the global range is new. The UDBHR is of utmost importance, because it is the first and, up to now, the only global bioethical instrument that was directly accepted by all states of the 
world, including South Africa (UNESCO 2005). All the other international influential instruments are either regionally bound (European Convention on Human Rights and Biomedicine 1997) or they focus on a specific profession such as the World Medical Association (WMA) Declaration of Helsinki, 2013. By accepting the UDBHR, all states also agreed to promote the principles in their distinctive countries in solidarity with each other (articles 23, 24; IBC 2008:45; Ten Have \& Jean 2009:17; UNESCO 2006). Langlois (2013), who researched the reception of the instrument in South Africa and Kenia, indicated that its influence is limited in these countries, saying:

[T]he Universal Declaration helps put bioethics on the agenda of States ... It appears to have had little or no impact in South Africa, however, on what is a growing and developing bioethics community. (p. 154)

The aim of this article is to formulate a Protestant ethical foundation for article 17 of the UDBHR. Vorster (2017:33, 243) understands the quest for a theological foundation as the study of Scripture to determine whether a specific human ethical idea could be associated with the Biblical message - in other words, what would Scripture say about the global principle declared in article 17? Article 17 ('Protection of the environment, the biosphere and biodiversity') reads as follows (UNESCO 2006):

Due regard is to be given to the interconnection between human beings and other forms of life, to the importance of appropriate access and utilisation of biological and genetic resources, to respect for traditional knowledge and to the role of human beings in the protection of the environment, the biosphere and biodiversity. (n.p.)

According to Ten Have (2019:1-18), who made a probing analysis of article 17 of the UDBHR in a global context, the following three matters are addressed by this article (see also Mathooko 2016:529):

- The interconnectedness between the human and the environment;

- Access to water and food and protection and

- Traditional knowledge.

In this study, only the first aspect of article 17 will receive attention, namely, the interconnectedness between the human and the environment - in other words, between the environment and human health.

Why would it be necessary to present a Protestant ethical foundation for this article? There are two reasons. The first focuses on a UNESCO rationale and the second on a Protestant rationale. This article forms part of a larger academic project in which I am investigating the UDBHR theologically. I have already discussed the above two reasons in great depth elsewhere (Rheeder 2017, 2018, 2019a, 2019b) and will, therefore, only present a brief overview of them here. It is important from a UNESCO perspective that the UDBHR should have the widest possible support, which would undeniably contribute to its credibility. According to article 14 of the UDBHR, the inclusion of all faith traditions is a basic right; therefore, the exclusion of groups on any ground is rejected (UNESCO 2006). UNESCO (2003-2005) emphasises, in particular, that the consultations took place as widely as possible during the development of the declaration. Intensive discussions were held with Islam, Confucianism, Buddhism, Hinduism and Roman Catholic faith traditions, according to several sources (Gallagher 2014:135; IBC 2004:2-4; Ten Have \& Jean 2009:31). The Protestant faith tradition, however, was excluded from these consultations (Andanda et al. 2013). After the acceptance of the declaration in 2005, Prof Henk Ten Have, who had managed the process for UNESCO, remarked the following (Ten Have \& Jean 2009):

One lesson from the presentations and discussions was that although there are differing moral views, common values can be identified ... In the end official representatives of states, but also of cultures, traditions, and religions, could agree on 15 ethical principles of global bioethics. (p. 14)

The statement is not truly convincing, as the Protestant faith tradition did not give its response or consensus to the UDBHR. One could, therefore, agree with Andanda et al. (2013) that the Protestant faith tradition was excluded from these consultations. It has to be kept in mind that there are between 800000 and 1 billion Protestants amongst the more or less 3 billion Christians in the world (Pew Research Center 2011). The exclusion casts suspicion on the selfdefinition of the UDBHR as 'universal principles based on shared ethical values' (par. 10; UNESCO 2006). A Protestant foundation can start filling the gap left by the exclusion of the Protestant perspective by engaging in an informal discussion with UNESCO with a view to make a humble preliminary contribution to promote the credibility of the UDBHR.

From a Protestant perspective, it is also important to present a theological foundation. I have remarked above that the UDBHR defines itself as universal principles grounded in shared ethical values. The declaration bases the principles on the fact that the values are accepted by all or by the majority. The argument that the Protestant faith tradition merely has to accept these values because of a global consensus is not convincing. Epistemologically, the Protestant faith tradition does not base ethical values on consensus but on Christian sources. Matz (2017) (see also Pauls \& Hutchinson 2008:431) summarises this point of departure as follows:

For Protestants, Scripture is the ultimate authority for faith, life, and doctrine, and this is no less true in the field of social ethics ... Scripture is foundational for Protestant social ethics .... (loc 183)

For this reason, Vorster (2015:109), a human rights expert from the Protestant tradition, connects shared values to the second commandment (Ex 20:4-6), saying, 'Uiteindelik bied die geskrewe Woord die beginsels vir die etiek en is dit ook die toetssteen van alle etiese kodes en handelinge' ' $[E]$ ventually, the written Word provides the principles for ethics and that is the acid test for all ethical codes and acts'. The view of Van Leeuwen (2014:419) confirms this epistemological 
point of departure in his overview of the UDBHR from a Protestant perspective. An ethical code such as the UDBHR has to be tested based on Scripture. It does not mean, however, that natural law (human reason, emotion and democratic approval) is epistemologically rejected, but it has to be always tested according to Scriptural principles to constitute a complete Protestant social ethics (Douma 1997:70). The implication is the formulation of Scriptural arguments that accept or reject an ethical code, in this case, article 17 of the UDBHR. Up to now, no Protestant investigation has been made into article 17 and, therefore, this article could be regarded as an introductory attempt to fill the gap.

A possible reason why the declaration has not made an impact in South Africa yet is the fact that the country is predominantly Protestant and that a foundation appropriate to the Protestant faith tradition is lacking. Habermas (2012:324), Hauerwas (2012) and Rawls (1993:134) are of the opinion that followers of the Protestant faith tradition will find it difficult to internalise and apply the principles to the UDBHR in practice without a Protestant theological foundation. In the Protestant community of South Africa, such a foundation could promote the acceptance of the global principles of the instrument, including the principle contained in article 17.

The methodology that will be followed is that article 17 will firstly be briefly analysed. Secondly, the analysis will be evaluated and founded from a broad Protestant social-ethical perspective. Article 17 of the UDBHR will now be analysed and discussed.

\section{Analysis and discussion Points of departure}

Firstly, in analysing article 17 of the UDBHR, UNESCO sources and commentaries will be used as far as possible, with a view to describe the 'UNESCO perspective' as accurately as possible. Secondly, the juridical-hermeneutic stance is taken that the analysis will take place according to article 31 of the Vienna Convention on the Law of Treaties, which states (Kirby 2009):

[S]uch instruments are to be ... interpreted in good faith in accordance with the ordinary meaning to be given to the terms of the Treaty in their context and in the light of its object and purpose. (p. 73)

\section{The relationship}

Article 17 of the UDBHR presents a new global bioethical principle of which the basic viewpoint is that the environment and human health (biomedical ethics) should not be separated from each other (UNESCO 2008:66). '[E]nvironmental security is no longer peripheral to the issues of human health', Tandon (2009:253) wrote in his commentary on article 17. Several UNESCO commentaries express the opinion that the general point of departure of article 17 is utilitarian in nature, namely, that the environment could have far-reaching positive or negative consequences for human health (Hattingh 2014:234; Tandon 2009:247-250; Ten Have 2019:36). The environment is essential to health, which means the environment is valuable (Ten Have 2019: 2-3, 16, 20, 33, 45-48; UNESCO 2011:78).

Already in articles 1 and 14 of the UDBHR, the relationship between the environment and health is declared as a fundamental point of departure. Article 1 states that the scope of the declaration is addressing bioethical challenges that amongst others include the relationship between health and the environment. It reads as follows: '[T]his Declaration addresses ethical issues related to medicine, life sciences and associated technologies as applied to human beings, taking into account their social, legal and environmental dimensions' (Tandon 2009:249; UNESCO 2006). In article 14 , the fundamental relationship between human health and the environment is articulated even more clearly (Ten Have 2019:26, 49, 55, 108-109). The article states the principle of social responsibility of the government and all sectors of society is to improve the health of all people, because 'the enjoyment of the highest attainable standard of health is one of the fundamental rights of every human being' (article 14:1-2). Article 14 (sections a-e) formulates five actions (health determinants) that can improve or harm the health of people. The third determinant is articulated as the 'improvement of ... the environment' (article 14.2c; Tandon 2009:249).

Because of the relationship between the environment and human health as declared in articles 1 and 14 and, especially 17 , it is important that the environment should be protected (see article 17): ' $[D]$ ue regard is to be given to ... the role of human beings in the protection of the environment, the biosphere and biodiversity' (UNESCO 2006). A significant remark of Ten Have and Jean (2009) is as follows: '[T]he UDBHR recognizes that humans have a special responsibility to protect biodiversity and the biosphere within which human beings exist'. The reason for this responsibility is that protection of the environment can be regarded as a form of healthcare (see also Likinda 2016:273, 277; Ten Have 2019:39).

\section{Rationale}

In the above discussion, I have stated that the point of departure in article 17 is the supposition that there is a relationship between the environment and human health and that this relationship can have negative (and positive) effects on human health. The fact that the environment can have negative effects on human well-being leads to the responsibility to protect the environment. The question arises now, on what does article 17 base this point of departure? It is based on two arguments, namely, a philosophical and a practical foundational supposition. The philosophical foundation is found in the use of the concept of 'interconnectedness' and the practical foundation is found in the concepts of 'environment, the biosphere and biodiversity'. 


\section{Interconnectedness}

What is the philosophical foundation of the viewpoint that a relationship exists between the environment and human health? UNESCO states the following in article 17: '[D]ue regard is to be given to the interconnectedness between human beings and other forms of life' (UNESCO 2006). This statement is already found in the Preface of the declaration where the international community is encouraged to realise 'that human beings are an integral part of the biosphere' (par. 11; Tandon 2009:247-248; UNESCO 2006). The concepts of 'interconnectedness' and 'integral part of' presume a certain view of the human and nature. The UNESCO rejects a dualistic view that separates the human and the environment from each other. The human and nature are not opposing and separate realities in which the human is a neutral and innocent subject and nature is a danger and enemy; the evil does not transfer from nature to humans and threaten them. The neutral human is not surrounded by a hostile nature, which has to be dominated by the human. Nature might be the origin of diseases, but diseases also result from human intervention in nature (Ten Have 2019:92). It can rather be said that there is a deep relationship, an interconnectedness, an integral coexistence between the environment and the human. The human and the environment form an interwoven coexistence. It can be described as an interdependence. The human forms part of nature or the environment (UNESCO 2008:68). What the human does has value for nature and what happens in the environment has an influence on the human. The human being is also an ecological being. Nature alone cannot be blamed for the health condition of the human. The UNESCO does not deny the debate that focuses on the value of the human and the intrinsic and instrumental value of nature, but it rather departs from a philosophy of an interconnectedness existing between the environment and the human: '[T]he fate of nature and human beings cannot be delinked. Rather that attributing value to either human or nature, it is a relationship that should be valued' (Ten Have 2019:71). Within this interconnectedness and the integrated totality, it happens that the human harms nature, which in turn leads to nature having a harmful or detrimental effect on the health of the human. Because the human and nature reciprocally influence each other and the environment can harm the human, the human stands in an ethical relationship with the environment, biosphere and biodiversity (Ten Have 2019:39, 50, 71-72).

\section{Environment, biosphere and biodiversity}

What is the practical reason for the supposition that an integral relationship exists between the environment and health? Brief attention will now be given to practical examples to demonstrate the relationship between the environment, the biosphere and biodiversity. Article 17 uses these three concepts, namely, 'environment', 'biosphere' and 'biodiversity', to prove the interconnectedness between the environment and human health: ' $[D]$ ue regard is to be given to the role of human beings in the protection of the environment, the biosphere and biodiversity' (UNESCO 2006).
Both Hattingh (2014:229) and Ten Have (2019:20) are of the opinion that currently these concepts are not clear and that no acceptable universal, objective and scientific definitions exist (see also Likinda 2016:276). Despite the similarities and differences, the terms are generally used as synonyms and most commentators prefer to use an overarching term such as 'earth system' (Hattingh) or 'all living things' (Ten Have). Article 17 of the UDBHR uses the term 'forms of life': '[D]ue regard is to be given to the interconnectedness between human beings and other forms of life' (UNESCO 2006). Broadly speaking, these concepts could be described as follows: environment indicates the large totality as well as the requirements for life in general (water cycle, photosynthesis and absorption of heat); biosphere refers to smaller, relative independent sections of the environment and it is a geographical term; biodiversity indicates the differences in species, between species and biospheres (Ten Have 2019:19-43; WHO 2015:1-43).

In the discussion of the practical reason the emphasis will now be on a few examples that indicate what the differences between the three concepts (environment, biosphere and biodiversity) are, whilst these examples will also demonstrate the negative relationship between nature and human health. It is impossible, however, to give attention to all the practical examples, which are many, in the limited space. The reader who is interested in more practical examples is advised to consult the following two comprehensive works: Connecting Global Priorities: Biodiversity and Human Health A State of Knowledge Review by the World Health Organization (2015) and a book by Ten Have (2019), namely, Wounded Planet: How Declining Biodiversity Endangers Health and How Bioethics Can Help. It has to be noted that the UDBHR indicates in its Preface that the information documents of the World Health Organization (hereafter WHO) can be used as background in explaining the instrument (par. 6; UNESCO 2006).

Human activities have a big impact on the environment. An example is the effect of air pollution, which presents a serious challenge to humans (WHO 2015:63-74). Air pollution is associated with approximately 6.5 million deaths worldwide per year, with $50 \%$ of the deaths occurring in China and India. Diseases generally connected with air pollution are cancer, cardiovascular and chronic lung diseases. The biggest cause of air pollution is the production of energy. It is said that in 2013, approximately 23000 premature deaths, 12000 new cases of chronic bronchitis and 21000 hospitalisations occurred because of power generation in the European Union. Air pollution is a global problem, because the poisonous substances released by coal in generating power affect people in countries that do not burn coal themselves (Ten Have 2019:23-25, 74, 102-103).

It is known that biodiversity found in the shape of trees (and in the shape of plants) plays an important role in the quality of air in the biosphere. Trees can remove a large quantity of pollution from the air. In some cases, however, biodiversity is destroyed by pollution, especially when the leaves 
are seriously damaged (Likinda 2016:274). In addition, biodiversity is also destroyed by habitat destruction and misuse. In this way, the destruction of biodiversity indirectly contributes to air pollution and accompanying health problems (Hattingh 2014:232; Ten Have 2019:4, 65). Ironically, the health industry also carries some of the blame for air pollution. Weaver (2016:2772) comments on the situation, saying, ' $[B]$ ioethicists are increasingly documenting the impact the health-care industry has on the environment'. The health industry is a large energy consumer that produces millions of tonnes of waste and carbon dioxide per year (Fiore 2016). There is also a serious indictment of an alarming connection between the generation of energy, air pollution and health problems in South Africa (Olutola \& Wichmann 2020).

A biosphere is a geographic area where diversity exists in symbiosis. Biodiversity is fundamental to the optimal functioning of a biosphere (Likinda 2016:274, 276). Ten Have (2019:41) states that 'human health ... and healthy ecosystem are linked'. The human is part of the biotic community or biosphere. There is an interconnectedness of existence. Bilharzia (schistosomiasis) is a big problem in sub-Saharan Africa (WHO 2015:56-59). Approximately 76\% of the population of sub-Saharan Africa lives close to rivers, lakes and other water resources. The disease infects almost 300 million humans worldwide, and nearly $93 \%$ of the infections occurs in sub-Saharan Africa. Bilharzia seriously affects the internal organs (liver, intestines and bladder), whilst it also inhibits the growth of children. Schistosomiasis is caused by a parasitic worm that lives in a water snail as its host for a large part of its life cycle. People are infected when the worm leaves its host and penetrates the skin. In Malawi, overfishing has been identified as a reason for the increase in infections. Fish are the natural enemies of the water snail host. Overfishing has, therefore, resulted in an increase in water snail hosts and, therefore, of the harmful worms. In this way, the number of infections is on the increase. In Cameroon, deforestation is associated with bilharzia. Deforestation increases sunlight penetration, causes changes in the flow rate of water, as well as varying water levels, and an increase in plant growth. These changes in the biosphere contribute to the increase in the number of water snail hosts, which should not have happened (Likinda 2016:274). The flow of infected water is not limited to a single region or country (Hattingh 2014:232, 234). The disease is also a big problem in South Africa. The parasite is brought to South Africa by infected immigrants from sub-Saharan Africa (Chimbari Moses et al. 2017).

A special connection exists between biodiversity, mental health and cultural life (Ten Have 2019:65-66; WHO 2015:200-219). A brief reference to the indigenous Mbya Gurani community, who lives in the sub-tropical forests of Yaboti, Argentina, South America, demonstrates this statement. This community uses approximately 150 medicinal plant species, 35 plant and 94 animal species as food, 54 species as raw materials for rituals, artefacts, weapons and building, whilst 61 species are used for fuel (biomass). With the destruction of the environment, mainly by foreigners (construction companies from Brazil), the health system, rituals and well-being of the community are negatively influenced. Deforestation destroys the following: (1) biospheres and diversity; (2) resources such as drinking water, fresh air, materials for rituals, artefacts and buildings, natural food (plants and animals); (3) spaces for houses, temples and villages, small-scale farming, medicinal plants, natural smells, sounds and the colour of landscapes (very specific environment for ceremonies); (4) the well-being of the communities and the happiness of the forefathers; and (5) the indigenous culture, which includes traditional medicine and health science. All these losses in biodiversity have led to big physical and psychological health problems in this indigenous community (Likinda 2016:279). In South Africa, depression is also connected with the lack of access to green landscapes (Tomita et al. 2017).

The losses in biodiversity are well known: dinosaurs, dodos, mammoths and passenger pigeons. It is generally accepted that almost 150 species are lost every day (Likinda 2016:274). Some other facts are (Ten Have 2019:25):

- One out of every four mammals and one out of every eight bird species are endangered.

- Forty one per cent (41\%) of amphibian species, 33\% reef building corals and $30 \%$ of pine tree species are endangered.

- The existence of 9000 animal species is endangered.

- Eight thousand and five hundred (8500) plant species are endangered.

- Every year, about 7.3 million hectares of forests are lost.

- The majority of tropical forests have already been destroyed.

- During the past 35 years, the original biodiversity has been reduced by more than a quarter.

These losses are caused by pollution, overutilisation of natural resources, ozone depletion, habitat destruction and fragmentation, soil erosion and climate change. The loss of biodiversity is tragic because of two reasons: (1) the loss is irrevocable and (2) humanity does not realise the medicinal potential the world is losing. About 1.8 million species are known, but it is surmised that there are between 5 million and 30 million species. Biodiversity has to be protected as a potential medicinal source for the present and future generations (Hattingh 2014:233, 240; Ten Have 2019:23-26, 70; WHO 2015:2).

In sum, three conclusions can be made from the analysis of the global principle. Firstly, the international community is convinced thatanirrefutablerelationship (interconnectedness) exists between the environment and human health. Secondly, this assumption is based on two reasons. The first reason recognises a philosophy of interconnectedness and the second is found in practice within the environment, biosphere and biodiversity. Thirdly, because of the relationship between the environment and human health, the protection of the 
environment, biosphere and biodiversity is an urgent obligation.

Subsequently, a Protestant ethical perspective on this global principle will now be discussed - in other words, can the Protestant faith tradition give its consent to this principle together with the global community?

\section{A protestant perspective}

In the light of the analysis of article 17 of the UDBHR, it will now be determined whether the following concepts can be Biblically approved: (1) interconnectedness between the human and the environment and, because of this relationship and (2) the obligation to protect nature. Before giving attention to these bioethical concepts, it is important to make a few remarks on hermeneutics.

\section{Hermeneutics}

Already in 1954, the Protestant theologian Joseph Sittler had the vision that a 'theology of the earth' had to be developed (Horrell 2011:255). This vision is noteworthy because it was articulated long before the publication of the influential Silent Spring (1962) by Rachel Carson, the founding of Greenpeace (1971) and Friends of the Earth (1972), as well as the sensational article by White (1967), in which he criticises the Christian life and world view as the most important reason for ecological problems. The statement was also made long before the well-known Protestant theologian Jürgen Moltmann (1985) pleaded for Christian ecological awareness.

The question now arises how Scripture should be approached in developing a 'theology of the earth', which can be used to evaluate article 17 of the UDBHR. Up to and including the influential work of Thomas Kuhn, under the influence of positivism, it was accepted that practising science (and Scriptural hermeneutics) is a neutral and objective act. Science and hermeneutics were separated from all paradigmatic assumptions. With the rise of the postfoundational philosophy of science, the subjectivity of science and hermeneutics was recognised and it was accepted that there would always be a 'leitmotiv as a presupposition' when practising science. A paradigmatic point of departure just have to be acknowledged (Vorster 2017:362). In the Protestant tradition, there are broadly two paradigmatic approaches to Scriptural hermeneutics in formulating Biblical perspectives on ecological challenges.

The first hermeneutical approach was developed by the Earth Bible Project (hereafter EBP), which is stationed in Australia. The work of the EBP is currently continued by the Society of Biblical Literature Seminar, which focuses on the Bible and hermeneutics. The EBP described its hermeneutics in five volumes, which were published under the editorship of Norman C. Habel between 2000 and 2002. The Society is convinced that the Bible makes contradictory ethical statements about the human relationship with nature. This means that Bible commentators choose eco-friendly texts selectively so that the anthropocentric texts can still be used to the disadvantage of a good relationship. To solve this problem, the EBP develops six 'ecojustice principles' (i.e. the principle of intrinsic worth, interconnectedness, voice, purpose, mutual custodianship and resistance) in dialogue with ecologists. The principles can be used as the basis for the critical evaluation of Biblical texts (Conradie 2006:310). Horrell (2011) summarises this approach as follows, saying:

$[T]$ he biblical texts are then read in light of these ecojustice principles and found to warrant positive recovery or negative resistance according to whether and how they cohere with the principles. (p. 258)

An example is that Habel rejects all efforts to mitigate the clear anthropocentric meaning of Genesis 1:26-28; therefore, he has no option but to reject the verses as an unfortunate insertion in the light of the eco-principles (Habel 2000:46-47). From a Protestant perspective, this point of departure is problematic, as the authority is shifted outside the Bible or the Christian tradition (Horrell 2011:258).

This last criticism leads to the second approach, which is defended by several Protestant theologians. A special example of this approach is found in the hermeneutics suggested by the well-known theologian, namely, Ernst Conradie who focuses on ecology and the Bible (Horrell 2011:259). The viewpoint of Conradie (2006) is that the use of 'Biblical keys' (also called heuristic keys, themes and motives) could be an important and responsible methodology in Biblical hermeneutics. He explains these keys, saying:

$[T]$ he keys are not directly derived from either the Biblical texts or the contemporary world but are precisely the product of previous attempts to construct a relationship between text, tradition and context ... Doctrinal keys are comprehensive theological constructs which may be used to establish a relationship between the Biblical texts and a contemporary context. (p. 306)

One could reason that the text, texts and tradition construct the theme, after which the theme can be used to evaluate the text, texts and contexts. Conradie refers to stewardship as an example of such a key. The use of themes as hermeneutic points of departure is accepted and applied by several Bible commentators in the Protestant tradition. In this connection, Moltmann (1977) and Vorster (2017) should be mentioned. Theologians working specifically in the field of bioethics are Childress (2002), Douma (1997), Macaleer (2014) and Rusthoven (2014).

It has to be recognised that a variety of moral positions coexists in Protestantism; thus, it will be difficult to find a universally accepted Protestant position with regard to any bioethical challenge. The approach in this study is, therefore, not connected with any specific tradition within Protestantism, precisely to promote the universality and credibility of article 17 as far as possible in Protestantism. Childress (2002), therefore, recommends that one or more Protestant themes have to be selected on the basis of which a bioethical problem can be investigated. With a thematic 
approach, this study also follows the broad thematic approach of the UNESCO research series with the title 'Advancing Global Bioethics' in their discussion of the relationship between the UDBHR and broad Protestant theology (see 'Religious perspectives on social responsibility in health', in Tham, Durante \& Gómez 2018). An attempt will now be made to develop a Protestant foundation for article 17 grounded in the relevant themes of creation, sin, covenant, Christology and eschatology.

Theological ethics as a science is closely intertwined with the total field of theology which, on the one hand, benefits from the insights of other theological disciplines but which, on the other hand, also wants to make its own contribution (Van Wyk 1986:15). Several theologians believe that theological ethics can not only focus on scientific deepening but also have the duty to either confirm or criticise claims to truth in society and culture with the existing theological insights (testing according to Vorster) (Plantinga, Thompson \& Lundberg 2010:19). Nullens and Volgers (2010:127) warn against exclusive and extreme specialisation in theology that could lead to the loss of public relevance. The unique contribution of this study tests the most recent global bioethical principles of the UDBHR using the latest Protestant theological insights and aims to contribute to the public awareness and acceptance of global bioethical principles within the Protestant faith tradition.

\section{Creation}

God as the creator of heaven and earth ( $\mathrm{Gn} 1: 1)$ is a prominent theme in both the Old Testament (Is 40:28; 42:5; 45:18) and New Testament (Mk 13:19, Rv 10:6, McKim 2017:216). Creation, the human and the Sabbath were created by God and the narrative of creation bears testimony to the fact that God himself saw all three of them were good (Gn 1:31, McKim 2017:216-217). The fact that creation, the human and the Sabbath were good in the eyes of God is reconfirmed in the New Testament (Rm 11:36, Tm 1 4:4, Horrell 2011:190).

What does it mean that creation was good in the eyes of God? Being created good indicates the high inherent dignity of creation (Horrell 2011:190; McKim 2017:217). Therefore, precisely because of the inherent dignity of creation, it is found that already before the fall into sin, God stated the principle that the human has to respect creation. He said to the human that he was not allowed to eat 'from the tree of the knowledge of good and evil'. The human had to leave the diversity alone and protect it. The reason for the command was that the destruction of biodiversity had also serious health implications (death) for the human being (Gn 2:17 - New International Version). In his commentary on the narrative of creation before the fall into sin, Frame (2008:269) interprets the above truth as follows: 'And we must protect plant and animal life, and their habitats, if we and our descendants are to survive'.

What does it mean that the human was created good? In general, the expression is interpreted as an indication that the human, who was created in the image of God, has dignity. In addition, commentators on Scripture indicate that this expression also means the human was created as an interconnected (bound to earth) being. The human is not only like God but also like creation. The human-created like creation shares the same substance as creation (Gn 2:7; 3:19). As a creature, the human was made by God from the same ground and clay as the plants and trees covering the earth (Vorster 2017:359). '[O]ur very creatureliness is something we have in common with nature, rather than with God', is the argument of Frame (2008:269). According to Moltmann $(1985: 18,51)$, the human was named 'earth' ('Adam'), which indicates that humanity is also the image of the earth. To be imago mundi means the human 'remains bound up with the earth' and implies that the human and creation cannot be separated from each other. Because of this created relationship, the narrative of creation wants to bring it urgently to the attention of the human that what happens to the one will also happen to the other. When nature is harmed, the human is harmed, and impairment of the human means per definition impairment of nature.

What does it mean that the Sabbath is a good institution? Moltmann (1985) judges as follows about the meaning of the creation of the human and the institution of the Sabbath:

It is true that, as the image of God, the human being has his special position in creation. But he stands together with all other earthly and heavenly beings in the same hymn of praise of God's glory, and in the enjoyment of God's sabbath pleasure over creation, as he saw that it was good. (p. 31)

The human and creation stand together. There is interconnectedness: together the human and creation (environment, biosphere and biodiversity) should enjoy the Sabbath (Ex 20:8-11). They have equal dignity: one cannot rest without the other. The rest of the human also implies the rest of the nature; if nature is unable to rest, the human also cannot rest (McKim 2017:217).

Already in the creation narrative, it is to my mind clear that the ideas found in article 17 of the UDBHR, namely, that interconnectedness exists between the human and the environment and that creation has to be protected, find strong support in Scriptural thinking.

\section{Sin}

The creation of the human as an interconnected being also has a great potential danger for the human and creation. The command Adam and Eve received to protect biodiversity was given to them as a covenantal command they had to obey. It implied that disobedience would have serious consequences (Gn 2:16-17; 3:17). As already indicated above, the human received the command to protect a part of the biosphere. The narrative emphasises the fact that the human ignored the covenantal command of God, in this way trying to demonstrate their carte blanche to God and creation. A sinful will and deeds had become part of humanity. Serious consequences for the human were the reality of death as well 
as a changed heart that would be continually disobedient to God (Kreider 2019b:219).

The disobedience of the human also had serious consequences for nature. The earth is no longer only a human-friendly and idyllic environment, it is a transformed environment that could have serious detrimental effects on human health. It now produces thorns and thistles (Gn 3:18). The environment can now tear humans apart, kill them (Jdg 8:7) and harm and inflict pain on the human body (Ezk 28:24). Creation displays an aggression that hits the human being with its 'fists' and can cause him serious injuries (2 Cor 12:7). In the narrative of Jesus, the thorns in the shape of a crown on his head are connected with his physical and psychological suffering and eventually his death (Mt 27:29, Jnh 19:2-5). Thorns symbolise the interconnectedness between creation and the human, as the environment can lead to the suffering and death of the human. Grudem (2010) wrote the following:

Here the expression 'thorns and thistles' functions as a kind of poetic image, a specific, concrete example that represents a multitude of things - such as hurricanes, floods, droughts, earthquakes, poisonous plants, poisonous snakes and insects, and hostile wild animals - that make the earth a place in which its natural beauty and usefulness are constantly mixed with other elements that bring destruction, sickness, and even death. Nature is not now what it was created to be, but is 'fallen'. (pp. 321-322)

In this theme of the fall into sin, it is important to note that mention is not only made of a one-way movement where nature harms the human but also of the opposite movement where 'because of you' (NIV) the ground is cursed, as God states clearly (Gn 3:17-18) (Kreider 2019b:219). It is the human's doing that there are thorns and thistles now. Through the decisions and actions of the human, creation has been affected and transformed in such a way that a destructive interconnectedness now exists between creation and the human being. The human's actions affect creation and in turn creation can harm the human (O'Brien 2010:139).

The theme of the fall into sin supports the point of departure of the UDBHR that nature can be affected because of the irresponsible deeds of the human, which in turn leads to the fact that the best interests of the health of the human can be affected. This discussion has confirmed that a relationship exists between creation and health.

\section{Covenant}

The narrative of Noah and the Ark tells the story of God's covenant of grace or his relationship with all humanity (Gn 6-9, Moltmann 1999:110). Three matters that are important for the theme of this study are found in this story. Firstly, a prominent idea is found again: when creation is severely harmed because of the selfish deeds of the human, it is followed by reverse events - this time a big water flood causes the death of humans. The fact the human had become corrupt and that his thoughts were evil (Gn 6:5-7, 12 - NIV) grieved God, which led him to destroy the human and creation by a flood (Gn 7:21). It is clear that the human and creation exist in an interconnected relationship in which the actions of the human harm creation, and creation severely harms the health of the human. In this regard, O'Brien (2010) writes that:

$[I] \mathrm{t}$ is unequivocally clear that the root cause of the flood was human wickedness. This is a story about the reality that all creatures suffer the consequences of bad decisions on the part of one species. (p. 139)

Secondly, within the reality of destruction, it is found that God is still protecting and preserving the human and nature (Kreider 2019a:224). God expected Noah to build an ark and commanded him to take his family and a big diversity of natural life into the safe environment of the ark with the purpose 'to keep their various kinds alive throughout the earth' (Gn 7:3). The fact that God protected the human and creation together is also 'an expression of the same interconnected thinking reflected in the covenant: we are graced by God alongside other creatures, and we will survive only alongside other creatures', is the opinion of O'Brien (2010:138). It is clear that the protection and interconnectedness of the human and creation are inclusive concepts that cannot be separated from each other.

Thirdly, after destroying and saving the human and nature, God made a covenant with Noah. He promised he would never again destroy the human and creation by a water flood and gave the rainbow as a symbol of the promise (Gn 8:22; 9:9-10). The fact that the covenant was made with the human being and all living creatures is an indication of the interconnectedness of existence (Moltmann 1999:113). God's promise that he would not destroy the human and creation again indicates his will that nature should be protected. According to Moltmann (1999:110), this covenant points to the right of creation to be protected. From the covenant, it is clear that interconnectedness and protection are two concepts inherent to the message of the Bible.

The notion of the relationship between the human, environment and health is illustrated even more clearly in the covenantal story of Exodus. The first 15 chapters of Exodus deal with the liberation of the covenantal people from the power of an oppressive regime. According to Olson (2011:294-295), this story connects the ethical principle of justice with ecology. The narrative of the 10 plagues is of special importance, as the story of the fall into sin is repeated here. God sent a series of plagues or ecological disasters (polluted land and water, harm to the environment, threats to food security, climate change) to the Egyptians with the purpose of convincing the pharaoh to set the covenant people free from slavery and oppression. All the ecological disasters had the potential to make the human seriously ill, even causing them to die. During the sixth plague, God instructed Moses and Aaron to take handfuls of soot from the furnace and toss it into the air before the pharaoh (Ex 9:8-11). Soot was probably a by-product of wood burning in the Egyptian furnaces and it was expected from the Israelites to operate 
the furnaces under difficult circumstances (Ex 1:8-14; 5:7-19). According to the Biblical text, humans and animals became seriously ill (festering boils) after the soot mixed with the air or atmosphere and a fine dust formed (Ex 9:9). According to Mazokopakis and Karagiannis (2019:311-312), it is possible that microbes developed in the carcasses of dead animals (fifth plague) and were transferred to humans by mosquitos (third plague) and flies (fourth plague), which also caused the terrifying disease. Mazokopakis and Karagiannis (2019) summarise the application of the sixth plague as follows:

[... T] he sixth Egyptian plague, as described in the Book of Exodus, constitutes the earliest medical report on the detrimental impact of soot/dust upon the human health and the environment, which is now well-known, having been documented over time since then. (p. 312)

As in the case of the fall into sin, it is not a movement in one direction where the environment causes the sickness of the human; that is, it is not only a movement from creation to the human, but there is also a movement from the human to creation. On the one hand, it is clear from Exodus that the direct action and insensitive decision of the pharaoh (not stopping the oppression) led to environmental disasters (Ex $7: 22 ; 8: 32 ; 9: 34)$; on the other hand, it is clear that humans were the cause of the dangerous dust (Olson 2011:295). Through the decisions and actions of the human, creation is affected and transformed. The decisions and actions of the human affect creation, which can result in creation harming the human (O'Brien 2010:139).

The danger presumed in article 17 of the UDBHR, namely, that the human's damage to the environment, the biosphere and biodiversity has big disadvantages for human health, is confirmed by the covenantal message and forcefully brought to the attention of the Christian community. The story of the covenant again confirms the relationship between creation and human health and indicates why nature has to be protected.

\section{Christology}

I have already referred to the argument of White (1967) that the Christian faith has contributed to the development of science and technology in modern times with the sad outcome of the uncontrollable destruction of creation. It is generally accepted that a specific interpretation of the human image is responsible for this view and the related destruction. According to Genesis 1:26-28 (also 2:15), the human created in the image of God received the assignment to rule (râdâh) over and subject (kâbash) the earth. The Hebrew word for 'to rule' has the negative meaning of 'trample' or 'trampling' according to some commentators (Vorster 2017:357). God did indeed put everything under the feet of the human (Ps 8:7). In addition, 'subjection' has the connotation of brutal subjection of enemies as slaves in imprisonment (Stott et al. 2006:154). Such an interpretation of the human as the image of God gives some Protestants the rationale to reject the idea of protecting creation on the grounds that it would be unimportant; therefore, they can refuse to respond to the global call of article 17 of the UDBHR. The above explanation of God's command to the human to rule over the earth is not convincing because of two reasons.

Firstly, the context shows that the human, who is created in the image of God, has to be the steward of God on earth by ruling in his place over the earth (Horrell 2011:260). The earth belongs to God (Ps 24:1), which implies that the human does not have autonomy with regard to creation. God provides guidelines that determine the relationship of the human with creation. According to Frame (2008:743-744) and Vorster (2017:356-360), the following are guidelines of God for the human as a steward of creation:

- Creation has to be cared for (Pr 12:11).

- Creation should not be exhausted or abused, which implies that sources should be afforded the chance of recovering (Ex 20:10-11; 23:12, Dt 23:10). Where measures for recovering are ignored, it may be detrimental to all (2 Chr 36:20-21).

- Creation may not be abused (Dt 22:4; 25:4, Pr 12:11).

- Creation may not be expletively destroyed (Dt 20:19).

Secondly, an in-depth Christological contra-argument is verbalised by Lundberg (2011):

In view of the NT portrayal of Jesus as the true 'image of the invisible God' (Col 1:15), the work of the stewardly imagebearing takes on even crisper contours. (p. 191)

Several Bible commentators identify with Christ's explanation of what it means to be in the image of God and what its implication would be for the human in his relationship with creation (Lundberg 2011:191). Christ instructed his followers to love like He did (Jnh 13:34; 15:12, Vorster 2017:165). A few examples are briefly discussed below.

God loved the world and so Christ came to the earth to carry the punishment for sin, so that the human would not be destroyed forever (Jnh 3:16). As Christ is co-creator of the cosmos (Col 1:15, Heb 1:2, Op 3:14), his incarnation also has redemptive meaning for the cosmos. It was part of Christ's work on earth to counteract destruction. It should not be overlooked that the redemptive love of God is not merely anthropocentric, but that it also includes the world or cosmos. It is the task of the human now to love creation redemptively by protecting it against destruction ( $\mathrm{Rm}$ 8:21, Lundberg 2011:190).

In addition, it has to be mentioned that Christ gave special priority to vulnerability. Lundberg (2011:191) connects vulnerability with creation when he refers to the emphasis Christ placed on human responsibility towards the interests of 'the least' (Mt 25:31-46). Although the human can also be vulnerable to the overwhelming force of creation, it does not mean that the environment, biosphere and biodiversity cannot be exceedingly vulnerable to the technological abilities of the human, as Ten Have (2019) confirms:

This sense of vulnerability and the need to protect nature from humans also inspired modern environmentalism - even more 
so, now that science and technology, and especially the atomic bomb as their contemporary product, can destroy life on the planet. (p. 6)

Creation can be 'sonder klere, siek of in die tronk wees' ['without clothes, sick or in prison'] and, therefore, human has to be the voice of the groaning creation (Vorster 2017:357). Creation has to be protected against the abuse of power precisely because destruction can cause diseases in the human (Mt 25:43-44).

Finally, Vorster (2017:357) also connects Christ's role as servant with the relationship of human with creation (Mk 10:45, Phlm 2:5-8). In one of his earlier works, Vorster (2007:13-20) develops an ethics of virtues (ethics of attitude), which is based on Philippians 2:5-8 and in which the servant role of Christ is central:

- Christ emptied himself, which means that He detached himself from his heavenly responsibilities with the purpose to be available on earth for the earth (Phlp 2:6).

- He made himself available as a slave with the purpose to serve the human and creation (Phlp 2:7).

- He humiliated himself (Phlp 2:8), which implies that $\mathrm{He}$ was the least, set his own interests aside and made certain sacrifices with the purpose of promoting the interests of the human and creation.

- He was obedient to God (Phlp 2:8), which means He fulfilled the will of God for the human and creation.

The human is, therefore, not in a relationship of anthropocentric domination of creation, but in a relationship in which he has the role of a servant that has to protect and promote the interests of creation in recognising the will of God (Lundberg 2011:191). Moltmann (1985:31) even mentions that the Sabbath, and not the human, is the high point of God's creation (Gn 2:1-3).

From a Christological perspective, being in the image of God means that creation has to be respected and protected. In this sense, Protestant ethics supports article 17, which calls upon the international community to protect creation. The unique contribution of Christology, which by its very nature is absent from article 17 of the UDBHR, is that conservation is inherently a form of service to God.

\section{Eschatology}

Eschatology deals with the events in the last period of existence of both the human and creation. An important notion in eschatology is the kingdom of God (Marshall 1995:354). Vorster $(2017: 136)$ is of the opinion that the kingdom as a present ('an already') and a future ('not yet') reality has become a prominent idea in Protestant thinking. As events in the present, the kingdom in its broken appearance was introduced with the coming of Christ (Mt 4:17, Matz 2017:loc 186) and will be transformed into an eternal kingdom of perfect glory (Col 3:4, Pt 2 1:11). This eternal kingdom becomes the content of believers' hope. Believers set their hope on the promise that the human and creation will be freed in the eternal kingdom. For the human and creation, it will be a place of glory freed from tears and destruction by war and death $(\operatorname{Rm~} 8,2$ Cor 4:17, Rv 21). Part of Christian hope is that God wants to free the human and creation from injustice, suffering and pain (Vorster 2017:112).

This eschatological vision, the eternal kingdom of hope, has now to be striven after as far as possible (Horrell 2011:259). Christ encouraged his followers, saying, 'But seek first his kingdom and his righteousness, and all these things will be given to you as well' (Mt 6:33). Righteousness means realising the 'armour of light' or the content of the eternal light of the kingdom as far as possible (Rm 13:12-13, Gill 1995:457). Moltmann (2012:7) explains the idea of light as part of armour, saying, '[A]s Paul, in his ethic of hope, calls for the "weapons of light", so the awakening of hope carries the promised future of righteousness into one's own life'. The citizens of the kingdom are inspired and called upon to show now already through their ethical actions where they are going (Du Rand 2015:215). What is the future righteousness that has to be striven after now? Future righteousness would mean that decisions and actions should have the aim to improve people's lives (without tears), to create an environment in which life can flourish (absence of war) and where one can promote health (no more pain and death) (Marshall 1995:354). A special way of improving the lives of humans is to create a favourable environment and to protect health by protecting and caring for creation. Kreider (2019b) refers in this connection to the eschatological vision that is found in Revelation 11:18, where God judges people 'who destroy the earth' and comments as follows on this text (see also Is 11:5-9):

Destruction of the planet is not merely accomplished by active and wilful rebellion. Passivity, too, is failure to care for the earth and is tantamount to destroying it ... Several practical implications follow. (1) Creation care is a gospel concern, for it is a life issue. Healthy human and animal life depends on a good environment that includes clean air and water and one in which disease and decay is controlled. (p. 221)

From the eschatological perspective, protection and respect for creation are emphasised. In this sense, there is eschatological support for the content of article 17.

\section{Conclusion}

The UDBHR is an important, modern human rights instrument regulating global bioethical challenges. The Protestant faith tradition was excluded from any discourse regarding the UDBHR; consequently, the universality and credibility, especially in Protestant circles, have been questioned. For the Protestant faith tradition, the voice of the Bible is decisive. An ethical foundation for article 17 is, therefore, important, as it can contribute to the internalisation of the principle. In the analysis of article 17, it has been shown that the international community is convinced that an irrefutable relationship exists between nature and the health of the human interconnectedness. A damaged creation harms the health of the human and, therefore, the protection of 
nature is an indisputable obligation. From a Protestant ethical perspective, this global principle could be associated with or founded on the themes of creation, sin, covenant, Christology and eschatology. Grounded in this preliminary evaluation, article 17 can be supported by the global Protestant community. A few facts from South Africa indicate the necessity of promoting the global bioethical principle in this country.

\section{Acknowledgements Competing interests}

The author declares that he has no financial or personal relationship that has inappropriately influenced him in writing this article.

\section{Author's contributions}

A.L.R. is the sole author of this research article.

\section{Ethical considerations}

This article followed all ethical standards for research without direct contact with human or animal subjects.

\section{Funding information}

This research received no specific grant from any funding agency in the public, commercial or not-for-profit sectors.

\section{Data availability}

Data sharing is not applicable to this article, as no new data were created or analysed in this study.

\section{Disclaimer}

The views and opinions expressed in this article are those of the author and do not necessarily reflect the official policy or position of any affiliated agency of the author.

\section{References}

Andanda, P., Schroeder, D., Chaturvedi, S., Mengesha, E. \& Hodges, T., 2013, 'Legal frameworks for benefit sharing: From biodiversity to human genomics', in D. Schroeder \& J.C. Lucas (eds.), Benefit sharing: From biodiversity to human genetics, pp. 33-64, Springer, Dordrecht.

Carson, R., 1962, Silent Spring, Houghton Mifflin, Boston, MA.

Childress, J.F., 2002, 'Protestant perspectives on informed consent: Particularly in research involving human participants', Fordham Urban Law Journal 30(1), 187-206.

Chimbari Moses, J., Manyangadze, T., Kabuyaya, M. \& Mukaratirwa, S., 2017, 'Schistosomiasis risk factors based on the infection status among school-going children in the Ndumo area, uMkhanyakude district, South Africa', Southern African Journal of Infectious Diseases 32(2), 67-72. https://doi.org/10.1080/2312 0053.2016.1266139

Conradie, E., 2006, 'The road towards an ecological biblical and theological hermeneutics: General', Scriptura: International Journal of Bible, Religion and Theology in Southern Africa 93, 305-314. https://doi.org/10.7833/93-0-1371

Douma, J., 1997, Medische ethiek, Kok, Kampen.

Du Rand, J.A., 2015, Omdat jy vry is: Ontsluit jou ware vryheid in Christus, Christelike Uitgewersmaatskapy, Vereeniging.

European Convention on Human Rights and Biomedicine, 1997, viewed 18 November 2020, from https://www.coe.int/en/web/conventions/full-list/-/conventions/ treaty/164

Fiore, R.N., 2016, 'Bioethics: Environmental', in H. Ten Have (ed.), Encyclopedia of global bioethics, pp. 313-324, Springer International Publishing, Cham.
Frame, J., 2008, The doctrine of the Christian life, Presbyterian and Reformed Publishing Co., Phillipsburg, NJ.

Friends of the Earth, 2020, 'History', viewed 18 November 2020, from https://www. foei.org/about-foei/history.

Gallagher, C.M., 2014, 'A Christian consideration of human vulnerability in healthcare and research', in J. Tham, A. Garcia \& G. Miranda (eds.), Religious perspectives on human vulnerability in bioethics, pp. 135-142, Springer, Dordrecht.

Gill, D.W., 1995, 'Hope', in D.J. Atkinson, D. Field, A.F. Holmes \& O.O'Donovan (eds.), New dictionary of Christian ethics \& pastoral theology, pp. 455-457, InterVarsity Press, Downers Grove, IL.

Greenpeace, 2020, 'Our history', viewed 18 November 2020, from https://www. greenpeace.org/usa/about/.

Grudem, W.A., 2010, Politics according to the Bible: A comprehensive resource for understanding modern political issues in light of Scripture, Zondervan, Grand Rapids, MI.

Habel, N., 2000, 'Geophany: The earth story in Genesis 1', in N. Habel \& S. Wurst (eds.), Earth Story in Genesis, pp. 34-48, Sheffield Academic Press, Sheffield.

Habermas, J., 2012, Nachmetaphysisches Denken, II: Aufsätze und Repliken, Suhrkamp, Berlin.

Hattingh, J., 2014, 'Protection of the environment, the biosphere and biodiversity', in H.A.M.J. Ten Have \& B. Gordijn (eds.), Handbook of global bioethics, pp. 225-250, Springer Science + Business Media, Dordrecht.

Hauerwas, S., 2012, 'Rights language and the justice of God', viewed 06 May 2019, from https://www.abc.net.au/religion/rights-language-and-the-justice-of-god/ 10100204.

Horrell, D.G., 2011, 'Ecological ethics', in J.B. Green, J.E. Lapsley, R. Miles \& A. Verhey (eds.), Dictionary of scripture and ethics, pp. 255-260, Baker Academic, Grand Rapids, MI.
Rad

IBC, 2004, Eleventh session [of the] International Bioethics Committee of UNESCO (IBC), UNESCO Headquarters, Paris, 23-24 August, International Bioethics Committee (IBC), viewed 18 November 2013, from http://portal.unesco.org/shs/ en/files/7495/11103874181ReportCIB11_en.pdf/ReportCIB11_en.pdf.

IBC, 2008, Report of the International Bioethics Committee of UNESCO (IBC) on consent, viewed 18 November 2020, from http://unesdoc.unesco.org/images/ 0017/001781/178124e.pdf

Kirby, M., 2009, 'Article 1: Scope', in H. Ten Have \& M. Jean (eds.), The UNESCO universal declaration on bioethics and human rights: Background, principles and application, pp. 67-80, Ethics series, UNESCO, Paris.

Kreider, G.R., 2019a., 'The apocalyptic and the enviroment', in D.S. Dockery \& T. Wax (eds.), Christian worldview handbook, pp. 223-226, B\&H Academic, Nashville, TN.

Kreider, G.R., 2019b, 'The Bible and creation care', in D.S. Dockery \& T. Wax (eds.), Christian worldview handbook, pp. 219-223, B\&H Academic, Nashville, TN.

Langlois, A., 2013, Negotiating bioethics: The governance of UNESCO's bioethics programme, Routledge, New York, NY.

Likinda, E.B., 2016, 'Biodiversity', in H. Ten Have (ed.), Encyclopedia of global bioethics, pp. 272-280, Springer International Publishing, Cham.

Lundberg, M.D., 2011, 'Creation ethics', in J.B. Green, J.E. Lapsley, R. Miles \& A. Verhey (eds.), Dictionary of scripture and ethics, pp. 189-192, Baker Academic, Grand Rapids, MI.

Macaleer, R.D., 2014, The new Testament and bioethics, theology and basic bioethics principles, Pickwick, Eugene, OR.

Marshall, I.H., 1995, 'Eschatology and ethics', in D.J. Atkinson, D. Field, A.F. Holmes \& O.O'Donovan (eds.), New dictionary of Christian ethics \& pastoral theology, pp. 354-355, InterVarsity Press, Downers Grove, IL.

Mathooko, J., 2016, 'Climate change and health', in H. Ten Have (ed.), Encyclopedia of global bioethics, pp. 524-531, Springer International Publishing, Cham.

Matz, B., 2017, Introducing protestant social ethics: Foundations in scripture, history, and practice, Baker, Grand Rapids, MI.

Mazokopakis, E.E. \& Karagiannis, C.G., 2019, 'Environmental and medical aspects related to the sixth plague of Egypt', Mædica: A Journal of Clinical Medicine 14(3), 310-313.

Mckim, D.K., 2017, 'Creation', in D.J. Treier \& W.A. Elwell (eds.), Evangelical dictionary of theology, pp. 216-218, Baker, Grand Rapids, MI.

Moltmann, J., 1977, The church in the power of the spirit: A contribution to messianic ecclesiology, transl. from German by M. Kohl, SCM Press, London.

Moltmann, J., 1985, God in creation: An ecological doctrine of creation, SCM Press, London.

Moltmann, J., 1999, God for a secular society: The public relevance of theology, SCM Press, London.

Moltmann, J., 2012, Ethics of hope, First Fortress Press, Minneapolis, MN.

Nullens, P. \& Volgers, R., 2010, Tussen 2 werelden: Een kennismaking met de Christelijke Theologie, Coconut, Almere.

O'Brien, K.J., 2010, An ethics of biodiversity: Christianity, ecology, and the variety of life, Georgetown University Press, Washington, DC.

Olson, D.T., 2011, 'Exodus', in J.B. Green, J.E. Lapsley, R. Miles \& A. Verhey (eds.), Dictionary of scripture and ethics, pp. 294-295, Baker Academic, Grand Rapids, Ml.

Olutola, B. \& Wichmann, J., 2020, 'South Africa: Air pollution, temperature and respiratory disease: A South African study', The Conversation, viewed 01 October 2020, from https://theconversation.com/air-pollution-temperatureand-respiratory-disease-a-south-african-study-141080. 
Pauls, M. \& Hutchinson, R., 2008, 'Protestant bioethics', in P.A. Singer \& A.M. Viens (eds.), The Cambridge textbook of bioethics, pp. 430-435, Cambridge University Press, Cambridge

Pew Research Center, 2011, 'Global Christianity: A report on the size and distribution of the world's Christian population', viewed 10 October 2020, from https://www. pewforum.org/2011/12/19/global-christianity-exec/.

Plantinga, R.J., Thompson, T.R. \& Lundberg, M.D., 2010, An introduction to Christian theology, Cambridge University Press, Cambridge.

Rawls, J., 1993, Political liberalism, Columbia University Press, New York, NY.

Rheeder, A.L., 2017, 'Respect for cultural diversity as a global bioethical principle: Own reasons from a Protestant perspective', HTS Teologiese Studies/Theological Studies 73(3), a4705. https://doi.org/10.4102/hts.v73i3.4705

Rheeder, R., 2018, 'Solidarity as a global bioethical principle: Own reasons for a culture of solidarity from a protestant perspective', Verbum et Ecclesia 39(1) a1816. https://doi.org/10.4102/ve.v39i1.1816

Rheeder, A.L., 2019a, 'Benefit-sharing as a global bioethical principle: A participating dialogue grounded on a protestant perspective on fellowship', In die Skriflig 53(1), a2502. https://doi.org/10.4102/ids.v53i1.2502

Rheeder, A.L., 2019b, Social responsibility for health as a global bioethical principle: A protestant participation in the discussion with UNESCO, Stellenbosch Theological Journal 5(1), 317-346. https://doi.org/10.17570/stj.2019.v5n1.a15

Rusthoven, J.J., 2014, Covenantal biomedical ethics for contemporary medicine: An alternative to principles-based ethics, Wipf \& Stock, Eugene, OR.

Stott, J.R.W., Mccloughry, R., Wyatt, J. \& Stott, J.R.W., 2006, Issues facing Christians today, 4th edn., fully rev. and updated, R. McCloughry, with a new chapter by J. Wyatt, Zondervan, Grand Rapids, MI.

Tandon, P.N., 2009, 'Article 17: Protection of the environment, the biosphere and biodiversity', in H. Ten Have \& M. Jean (eds.), The UNESCO universal declaration on bioethics and human rights: Background, principles and application, pp. 247-254, Ethics series, UNESCO Publishing, Paris.

Ten Have, H. \& Jean, M., 2009, 'Introduction', in H. Ten Have \& M. Jean (eds.), The UNESCO universal declaration on bioethics and human rights: Background principles and application, pp. 17-56, Ethics series, UNESCO Publishing, Paris.

Ten Have, H.A.M.J., 2019, Wounded planet: How declining biodiversity endangers health and how bioethics can help, Johns Hopkins University Press, Baltimore, MD.
Tham, J., Durante, C. \& Gómez, A.G., 2018, Religious perspectives on social responsibility in health: Towards a dialogical approach, Springer, Dordrecht. (Advancing global bioethics: 2).

Tomita, A., Vandormael, A.M., Cuadros, D., Di Minin, E., Heikinheimo, V., Tanser, F. et al., 2017, 'Green environment and incident depression in South Africa: A geospatial analysis and mental health implications in a resource-limited setting', The Lancet Planetary Health 1(4), e152-e162. https://doi.org/10.1016/S25425196(17)30063-3

UNESCO, 2005, 'Records of the General Conference, 33rd session, Paris, 3-21 October, vol. 1: Resolutions', viewed 18 November 2013, from http://unesdoc.unesco.org/ images/0014/001428/142825e.pdf.

UNESCO, 2006, 'Universal declaration on bioethics and human rights', viewed 13 November 2013, from http://unesdoc.unesco.org/images/0014/001461/ 146180e.pdf

UNESCO, 2008, 'Bioethics core curriculum. Section 1: Syllabus ethics education programme sector for social and human sciences, Division of ethics of science and technology', viewed 18 November 2013, from http://unesdoc.unesco.org/ images/0016/001636/163613e.pdf.

UNESCO, 2011, 'Bioethics core curriculum. Section 2: Study materials ethics education programme version', viewed 18 November 2013, from http://unesdoc.unesco. org/images/0021/002109/210933e.pdf.

Van Leeuwen, E., 2014, 'Protestantism', in H.A.M.J. Ten Have \& B. Gordijn (eds.), Handbook of global bioethics, pp. 419-427, Springer Science + Business Media, Dordrecht.

Van Wyk, J.H., 1986, Gesindheid en gestalte, N.G. Kerkboekhandel, Transvaal.

Vorster, J.M., 2007, Christian attitude in the South African liberal democracy, Potchefstroom Theological Publications, Potchefstroom.

Vorster, J.M., 2015, Christelike etiek in 'n sekulariserende samelewing, AOSIS Publishing, Durbanville, South Africa.

Vorster, J.M., 2017, Ethical perspectives on human rights, Potchefstroom Theological Publications, Potchefstroom.

Weaver, D.F., 2016, 'Sustainability', in H. Ten Have (ed.), Encyclopedia of globa bioethics, Springer International Publishing, Cham.

White, L., 1967, 'The historical roots of our ecological crises, Science 155(3767), 1203-1207. https://doi.org/10.1126/science.155.3767.1203

WHO, 2015, Connecting global priorities: Biodiversity and human health: A state of knowledge review, WHO, Geneva. 